\title{
Efek Penambahan Gula Terhadap Kestabilan Warna Ekstrak Fikosianin Spirulina sp.
}

\author{
Sri Sedjati*, Ali Ridlo dan Endang Supriyantini \\ Jurusan IImu Kelautan, Fakultas Perikanan dan IImu Kelautan, Universitas Diponegoro. \\ JI. Prof. Soedarto, SH. Kampus UNDIP Tembalang, Semarang 50275 \\ E-mail : sedjati69@gmail.com
}

\begin{abstract}
Abstrak
Mikroalga Spirulina sp. memiliki kandungan fikosianin yang berpotensi untuk digunakan sebagai pewarna alami, namun fikosianin tidak stabil terhadap suhu, cahaya, pH, dan oksigen, sehingga perlu ditambahkan pengawet. Penelitian ini bertujuan untuk mengetahui pengaruh pengawet gula terhadap kestabilan fikosianin yang diekstraksi dari Spirulina sp. Spirulina sp diekstraksi dengan akuades dan larutan buffer fosfat $\mathrm{pH}$ 7. Efek penambahan gula diamati selama 14 hari penyimpanan pada suhu kamar $\left(30 \pm 3^{\circ} \mathrm{C}\right)$. Stabilitas pigmen diamati berdasar nilai konsentrasi relatifnya $\left(C_{R}\right)$. Hasil penelitian menunjukkan bahwa kadar fikosianin Spirulina sp. yang diekstraksi dengan aquades adalah $45,16 \pm 1,13 \mathrm{mg} / \mathrm{g} \mathrm{dw}$, sedangkan untuk ekstrak dengan pelarut buffer fosfat $\mathrm{pH} 7$ adalah $760,51 \pm 0,11 \mathrm{mg} / \mathrm{g} \mathrm{dw}$. Penambahan gula fruktosa $5 \%$ memberikan hasil yang paling efektif selama 14 hari penyimpanan suhu kamar $30 \pm 30 \mathrm{C}$, konsentrasi relatif yang tersisa sebesar $19,39 \%$, sedangkan tanpa pengawet konsentrasi relatif hanya 10,57 \%. Secara umum penambahan gula (sukrosa, fruktosa dan glukosa $5 \%$ dan $10 \%$ b/v) mampu meningkatkan konsentrasi relatif menjadi 12,12-19,39\%.
\end{abstract}

Kata kunci : Fikosianin, Spirulina sp, gula, Aktivitas Antioksidan

\begin{abstract}
Microalga Spirulina sp. has a high content of phycocyanin. Phycocyanin has potential as a natural blue colorant. Phycocyanin is not stable against temperature, light, $\mathrm{pH}$ and oxygent. Preservatives are food additives commonly used to preserve unstable food. The purpose of this research was to screening sugar preservatives for phycocyanin. The effect of selected sugar preservatives, sucrose, glucose and fructose on the stability of phycocyanin at room temperature $\left(30 \pm 3^{\circ} \mathrm{C}\right)$ was studied in aqueous solution for 14 days. Pigment stability after 14 days storages was observed from concentration relative $\left(C_{R}\right)$ value. The result showed that phycocyanin content in aquadest extract was $45,16 \pm 1,13 \mathrm{mg} / \mathrm{g} \mathrm{dw}$. The $C_{R}$ value remained at approximately 12,12-19,39\% after storage for 14 days at room temperature when sugar preservatives (sucrose, glucose and fructose $5 \%$ and $10 \% \mathrm{w} / \mathrm{v}$ ) was added, while without preservatives $C_{R}$ value decreased to $10,57 \%$. The highest stability of the phycocyanin solution was found in adding fructose $5 \%\left(C_{R}\right.$ value $\left.=19,39 \%\right)$.
\end{abstract}

Keywords : Phycocyanin, Spirulina sp., Sugar, Antioxidant Activity

\section{PENDAHULUAN}

Kelompok pigmen fikosianin dapat mamancarkan warna biru (Prasanna et al.,2007), sehingga berpotensi untuk dikembangkan sebagai pewarna biru alami. Pemberitaan informasi tentang bahaya/efek negatif pewarna sintetis meningkatkan kesadaran masyarakat untuk kembali menggunakan produk pewarna alami. Saat ini pewarna alami pada umumnya berbahan dasar tumbuhan tingkat tinggi seperti daun pandan, daun suji, kunyit dan hanya 
dimanfaatkan secara tradisional. Secara komersial, keberadaan pewarna alami kalah bersaing dengan pewarna sintetis yang banyak dijual di pasaran.

Kendala dalam proses eksplorasi pigmen alami adalah rendahnya kestabilan warna baik ketika proses ekstrasi, pemurnian, maupun selama penyimpanan. Fikosianin akan pudar warnanya (terdenaturasi) pada suhu di atas $45^{\circ} \mathrm{C}$ atau pada $\mathrm{pH}$ di bawah 4 (stabil pada $\mathrm{pH}$ 4-9), namun fikosianin memiliki keunggulan, yaitu menghasilkan warna biru cerah dan cemerlang (Sarada et al., 1999; Jespersen et al., 2005; Yan et al., 2011).

Spirulina sp. merupakan mikroalga hijau-biru yang kaya pigmen. Pigmen yang terdapat di dalam Spirulina sp. dikelompokkan menjadi tiga kelas: (1) klorofil a terdiri dari 1,7\% dari berat sel, (2) karotenoid dan xantofil yang berkisar $0,5 \%$ dari berat sel, (3) fikobiliprotein/fikobilin yaitu fikosianin dan allofikosianin yang secara normal terdiri dari $20 \%$ protein seluler dan secara kuantitatif merupakan pigmen yang paling dominan pada Spirulina (Richmond, 1988).

Pigmen fikobilin merupakan pigmen yang berasosiasi dengan protein dan bersifat polar serta larut air, dapat diekstrak dengan menggunakan pelarut aquades atau buffer (Masojidek et al., 2004). Berdasarkan hal tersebut, perlu dilakukan penelitian tentang pengaruh penambahan bahan pengawet terhadap kestabilan fikosianin yang diekstrak sehingga bisa menambah daya simpan. Penambahan gula dicoba sebagai alternatif pengawet karena bersifat alami dan aman dikonsumsi sebagai bahan pangan.

Fikosianin harus melalui berbagai tahapan agar memenuhi syarat sebagai pewarna alami, yaitu: pengendapan dan pemurnian. Kemurnian ini diukur berdasar rasio $A_{620} / A_{280}$, pengukuran $A_{620}$ adalah nilai absorbansi fikosianin $(\lambda=620 \mathrm{~nm})$ dan $\mathrm{A}_{280}$ adalah nilai absorbansi protein $(\lambda=280$ $\mathrm{nm})$. Kriteria kemurnian fikosianin untuk pangan (food grade) minimal sama dengan 0,7. Beberapa penelitian bisa menghasilkan kemurnian 0,7 tanpa proses pemurnian. Proses pemurnian secara kromatografi dilakukan untuk memperoleh fikosianin murni dengan tingkat kemurnian di atas 4,0 (analytical grade) (RitoPalomares et.al., 2001; Hemlata et al., 2011; Prabuthas et al., 2011).

\section{MATERI DAN METODE}

Penelitian ini dilakukan pada bulan Juni - November 2014, di Laboratorium Marine Station Teluk Awur, Jepara, Fakultas Perikanan dan IImu Kelautan, Universitas Diponegoro. Bahan yang dipakai dalam penelitian ini adalah mikroalga Spirulina sp. komersial produksi Indonesia dalam bentuk kering (bubuk). Bahan-bahan kimia yang dipakai untuk ekstraksi dan analisis adalah aquades, gula (fruktosa, glukosa dan sukrosa p.a) dan kertas saring Whatman no. 42. Alat-alat yang digunakan meliputi neraca analitik, mortar dan penggerus, vortex, refrigerator, sentrifuse dan spektrofotometer UV-Vis.

Prosedur kerja penelitian terdiri dari beberapa tahap, yaitu: ekstraksi pigmen fikosianin, penambahan gula dan analisis kadar pigmen fikosianin. Metode ekstraksi yang digunakan adalah metode coldmaceration dan freezingthawing.Sampel kering Spirulina sp. digerus dengan mortar sampai halus. Sampel dimaserasi menggunakan pelarut aquades dengan perbandingan 1:100 (w/v), kemudian dihomogenasi dengan vortex selama 1 menit. Sampel dibekukan dalam freezer selama $12 \mathrm{jam}$, setelah itu sampel beku dicairkan selama 12 jam pada suhu kamar (1 siklus metode freezing-thawing) (dilakukan sebanyak 2 siklus), lalu disaring. Filtrat disentrifugasi dengan kecepatan 3000 rpm selama 30 menit. Larutan disaring dengan kertas saring sehingga di peroleh ekstrak kasar fikosianin Spirulina sp.

\section{Penentuan Spektra Absorbansi Pigmen Fikosianin}

Filtrat diukur absorbansinya menggunakan spektrofotometer pada kisaran panjang gelombang $280-750 \mathrm{~nm}$. Serapan maksimum fikosianin terletak 
pada panjang gelombang $610-620 \mathrm{~nm}$ (Prasanna et al., 2010; Saleh et.al., 2011).

\section{Analisis Kadar Fikosianin}

Filtrat fikosianin diukur absorbansinya menggunakan spektrofotometer UV-VIS pada panjang gelombang $280 \mathrm{~nm}, 620 \mathrm{~nm}$ dan $650 \mathrm{~nm}$. Kadar fikosianin dihitung dengan metode Bennet dan Bogorad (1973), sebagai berikut :

$$
\begin{aligned}
& P C\left(m g \cdot m L^{-1}\right)=\frac{\left.L A_{\Delta z 0}-\left(0.7 \times A_{i 50}\right)\right\}}{7.38} \\
& P C(m g / g)=P C\left(m g \cdot L^{-1}\right) \times V_{p} / D W
\end{aligned}
$$

Di mana :

PC : Kadar Phycocyanin

$A_{620}$ : Nilai Absorbansi pada (a) $620 \mathrm{~nm}$

$A_{650}$ : Nilai Absorbansi pada (a) $650 \mathrm{~nm}$

$V_{p} \quad$ : Volume pelarut (ml)

DW : Berat kering (g)

\section{Uji Kestabilan Warna}

Stabilitas larutan fikosianin selama masa penyimpanan suhu kamar dilakukan dengan menambahkan bahan pengawet gula (sukrosa, glukosa, fruktosa, masingmasing dengan konsentrasi $5 \%$ dan $10 \%$ $(\mathrm{b} / \mathrm{v}))$. Sebagai pembanding adalah pengawet sintetis asam benzoat (kontrol positif) dan tanpa gula (kontrol negatif). Masing-masing gula ditambahkan ke dalam $10 \mathrm{ml}$ larutan ekstrak fikosianin dan disimpan pada suhu kamar $30 \pm 3^{\circ} \mathrm{C}$. Kestabilan warna fikosianin diuji dengan menghitung konsentrasi relatif pigmen fikosianin selama masa penyimpanan yang telah ditentukan.

$$
C_{R}(\%)=\frac{C}{C_{0}} \times 100
$$

Di mana :

$C_{R}:$ konsentrasi relatif

Co : konsentrasi awal

C : konsentrasi pada waktu penyimpanan

\section{HASIL DAN PEMBAHASAN}

Fikosianin yang diekstrak dengan pelarut aquades menghasilkan pola spektra dengan puncak serapan $620 \mathrm{~nm}$.

Parameter kemurnian $\left(\mathrm{A}_{620} / \mathrm{A}_{280}\right)$ merupakan ukuran relatif berdasarkan rasio absorbansi pada panjang gelombang 620 $\mathrm{nm}$ dan $280 \mathrm{~nm}$.

Tanpa proses pemurnian, ekstrak kasar fikosianin sudah bisa mencapai tingkat kemurnian lebih dari 0,7 (Tabel 1). Hasil ini sesuai dengan penelitiannya sebelumnya, kandungan fikosianin pada Spirulina sp. berkisar $1-10 \%$ berat kering (Sedjati et al., 2012) Kandungan pigmen fikosianin yang tinggi tersebut menjadi daya tarik bagi pengembangan dan dianggap memiliki pasar potensial dalam industri pangan dan kesehatan, karena pigmen fikosianin juga memiliki karakteristik antioksidan (Chrismandha et al., 2006).

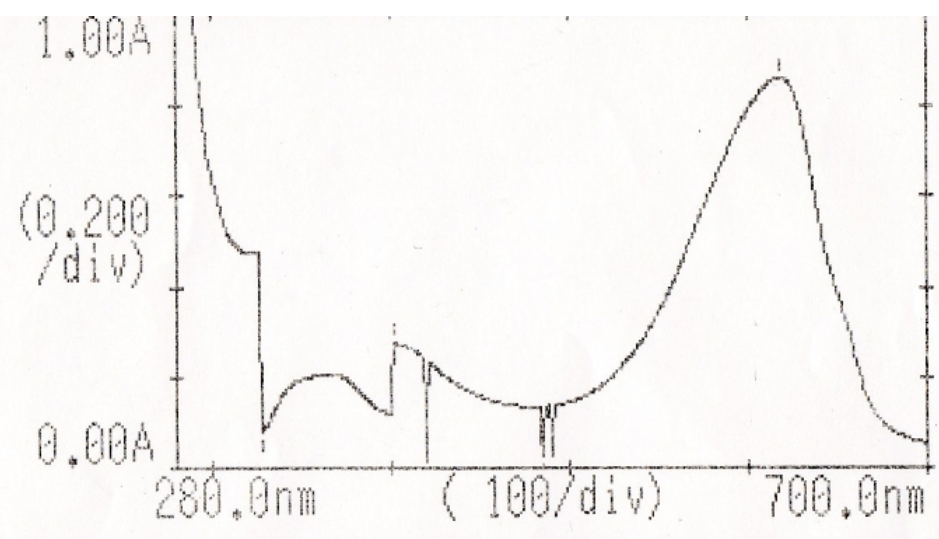

Gambar 1. Spektra Ekstrak Kasar Fikosianin yang Diekstraksi dengan Aquades (sampel:pelarut $=1: 100 \mathrm{~b} / \mathrm{v}$, pengenceran $5 \mathrm{x}$, puncak $\lambda=620 \mathrm{~nm}$ ) 
Tabel 1. Kadar dan Kemurnian Fikosianin

\begin{tabular}{cccc}
\hline Pelarut & $\begin{array}{c}{[\mathrm{PC}]} \\
(\mathrm{ppm})\end{array}$ & $\begin{array}{c}{[\mathrm{PC}]} \\
(\mathrm{mg} / \mathrm{g} \text { sampel DW) }\end{array}$ & $\begin{array}{c}\text { Kemurnian } \\
\text { (Rasio A620/A280) }\end{array}$ \\
\hline Aquades & $451,65 \pm 11,26$ & 45,16 & $1,61 \pm 0,05$ \\
\hline
\end{tabular}

Tabel 2. Konsentrasi Relatif Pigmen Fikosianin setelah Penambahan Gula selama Penyimpanan Suhu Kamar $30 \pm 3^{\circ} \mathrm{C}$

\begin{tabular}{ccccccc}
\hline \multirow{2}{*}{ Jenis pengawet } & \multicolumn{5}{c}{ Konsentrasi Relatif PC (\%) Hari ke- } \\
\cline { 3 - 6 } & & 0 & 2 & 5 & 9 & 14 \\
\hline \multirow{2}{*}{ PC+Fruktosa } & $5 \%$ & 100,00 & 96,93 & 65,41 & 35,32 & 19,39 \\
& $10 \%$ & 100,00 & 97,46 & 64,06 & 22,14 & 17,15 \\
PC+Glukosa & $5 \%$ & 100,00 & 93,15 & 43,92 & 22,77 & 13,18 \\
& $10 \%$ & 100,00 & 96,20 & 64,25 & 35,54 & 12,12 \\
PC+Sukrosa & $5 \%$ & 100,00 & 80,04 & 73,33 & 44,33 & 16,42 \\
& $10 \%$ & 100,00 & 93,75 & 66,63 & 37,46 & 17,53 \\
PC+A. Benzoat & $200 \mathrm{ppm}$ & 100,00 & 92,29 & 70,44 & 37,84 & 25,80 \\
\hline \multicolumn{2}{c}{ Kontrol negatif } & 100,00 & 75,57 & 47,66 & 22,38 & 10,57 \\
\hline
\end{tabular}

Kelemahan fikosianin adalah mudah pudar karena proses degradasi alamiah. Penambahan bahan pengawet gula diharapkan dapat memperpanjang daya simpannya. Penentuan konsentrasi pengawet asam benzoat (200 ppm) dan gula pasir (5\% dan $10 \%)$ berdasarkan peraturan Badan Pengawas Obat dan Makanan (BPOM) no. 36 Tahun 2013 tentang dosis bahan tambahan makanan. Konsentrasi maksimum asam benzoat yang diijinkan adalah 400 ppm untuk minuman berperisa berkarbonase atau tidak berkarbonase. Peraturan penambahan gula pasir pada bahan makanan minimal $3 \%$ dari bahan makanan.

Bahan pengawet gula yang menghasilkan penurunan konsentrasi relatif terkecil adalah pengawet gula fruktosa 5\% yang dicoba selama penelitian. Penambahan fruktosa sebanyak $5 \%$ mampu menghasilkan konsentrasi relatif dua kali lipat dibanding kontrol negatif (tanpa pengawet). Kemampuan 5\% fruktosa dalam mempertahankan kestabilan pigmen fikosianin mendekati asam benzoat 200 ppm.

Fikosianin dalam pelarut aquades lebih stabil dengan pengawet asam benzoat (200 ppm) pada suhu $30 \pm 3^{\circ} \mathrm{C}$. Konsentrasi fikosianin tanpa penambahan pengawet menunjukkan penurunan yang tinggi setelah 5 hari, konsentrasi fikosianin yang hilang adalah sebanyak $52 \%$. Setelah 14 hari masa penyimpanan, warna pigmen fikosianin hilang sebanyak $90 \%$. Warna biru semakin pudar seiring bertambahnya waktu penyimpanan. Hal tersebut terjadi karena nilai $\mathrm{pH}$ mempengaruhi kestabilan ikatan billiprotein dalam larutan. Menurut Duangsee et al. (2009), struktur kimia fikosianin akan terbuka pada $\mathrm{pH} \leq 4,5$ karena rusaknya ikatan hidrogen yang ada. Fikosianin tidak akan larut lagi pada larutan dengan $\mathrm{pH}$ kurang dari 3.

Nilai $\mathrm{pH}$ dalam larutan fikosianin yang ditambah gula berkisar 6-7, sedangkan yang ditambah asam benzoat berkisar 4-5. Beberapa pendapat menguatkan asumsi ini, pada $\mathrm{pH}$ rendah (asam) struktur molekul fikosianin akan mengembang, karena protein yang terdenaturasi, menggumpal dan mengendap sehingga struktur fikosianin rusak. Hal tersebut menyebabkan intensitas warna dan pembacaan absorbansi dengan spektrofotometer menurun (Duangsee et al., 2009). Semakin banyak protein yang mengendap maka nilai absorbansi dari fikosianin akan rendah 
dan sebaliknya (Bhaskar et al., 2005). Fikosianin dalam bentuk larutan, ditemukan sebagai gabungan yang kompleks dari monomer, trimer, hexamer dan oligomer lainnya (Chaikhlahan et al., 2014). Degradasi fikosianin bergantung pada kesatuan bagian dari protein, yang dipengaruhi oleh beberapa parameter seperti cahaya, suhu, pH dan konsentrasi protein (Jespersen et al., 2005).

\section{KESIMPULAN}

Penambahan pengawet gula pada ekstrak kasar pigmen fikosianin yang lebih efektif adalah fruktosa 5\%. Konsentrasi relatif $\left(C_{R}\right)$ selama 14 hari penyimpanan suhu kamar untuk fruktosa $5 \%$ adalah 19,39\%, bernilai lebih tinggi dibanding tanpa gula $\left(C_{R}=10,57 \%\right)$.

\section{DAFTAR PUSTAKA}

Bhaskar, S.U., Gopalaswamy, G. and Raghu, R. A. 2005.Simple method for efficient extraction and purification of Fikosianin from Spirulina platensis Geitler.Indian Journal of Experimental Biology. 43(3): 277-279.

Bennett, A. and L. Bogorad. 1973. Complementary chromatic adaptation in a filamentous bluegreen alga. J. Cell. Biol. 58: 419-435.

Chaiklahan, R., N. Chirasuwan, and B. Bunnag. 2012. Stability of phycocyanin extracted from Spirulina sp.: Influence of temperature, $\mathrm{pH}$ and preservatives. J. Process Biochem. 47: 659-664.

Duangsee, R., Phoopat, N. And Ningsanond S. 2009. Phycocyanin Extraction Fromspirulina platensis and Extract Stability Under Various $\mathrm{pH}$ and Temperature. As. J. Food Ag-Ind. 2(4): 819-826.

Edwards, M.R., C. Haver, R.F. Stack, L.E. Eisele, R. MacColl. 1997. Thermophilic C-phycocyanin: effect of temperature, monomer stability, and structure. J. Bioch et Bioph. 1321: 157164.

Estrada, J,E.P., P.B. Bescos, A.M. V. Fresno. 2001. Anti oxidant activity of different fractions of Spirulina platensis protean extract. II Farmaco 56: 497-500.

Hamid, A.A., O.O Aiyelaagbe, L.A. Usman, O.M. Ameen, A. Lawal. 2010. Antioxidant : its Medidal and Pharmacological Applications. African Journal of pure and applied chemistry vol.4(8), pp. 142-151

Hemlata, G. Pandey, F. Bano.T. Fatma. 2011. Studies of Anabaena sp. NCCU-9 with special reference to phycocyanin. J. Algae Biomass UtIn. 2(1): 30-51.

Jespersen, L., L.D. Stremdahl, K. Olsen, L.H.Skibsted. 2005. Heat and light stability of three natural blue colorant for use in confectionery and beverages. Europ. Food Res. Technol. 220(3-4): 261-266.

Masojidek, J., M. Koblizek, G. Torzillo. 2004. Photosynthesis in microalgae in: A. Richmond (Ed). Handbook of Microalgal Culture: Biotechnology and Applied Phycology. Blakwell Science Ltd., lowa. p.20-39.

Prabuthas, P., Majumdar S., Srivastav P.P., Mishra H.N. 2011. Standarization of rapid and economical method for nutraceuticals extraction from algae. J. Stored Products and Post Harvest Res. 2(25): 93-96.

Prasanna, R., A. Sood, A. Suresh, S. Nayak, B.D. Kaushik. 2007. Potential and aplications of algal pigment in biology. .Acta Botan. Hungaria 49 (12): 131-156.

Prasanna, R., A. Sood, P. Jaiswal, S. Nayak, V. Gupta, V. Chaudhary, M. Joshi, C. Natarjan. 2010. Rediscovering cyanobacteria as valuable sources of bioaktive compounds. Appl. Biochem. Microbiol. `46 (2): 119-134.

Rito-Palomoras, M., Nunez L., Amador D. 2001. Practical application of aqueous two-phase systems for the development of prototype process for C-phycocyanin recovery from Spirulina maxima. J. Chem. Techn. Biotechnol. 76: 1273-1280.

Sarada, R., M.G. Pillai, G.A. Ravishankar. 1999. Phycocyanin from Spirulina sp.: influence of processing of biomass on phycocyanin yield, analysis of efficiency of extraction methods and 
stability studies on phycocyanin. J.Proc. Biochem. 34:795-801.

Sedjati, Sri, Ervia Yudiati dan Suryono. 2012. Profil Pigmen Polar dan Non Polar Mikroalga Laut Spirulina sp dan Potensinya sebagai Pewarna Alami. Jurnal IImu Kelautan., Vol. 17 (3) 176 181.
Yan, S., Zhu LP, SU HN, Zhang XY, Chen XL, Zhou BC, Zhang YZ. 2011. Single-step chromatography for simultaneous purification of C-phycocyanin and allophycocyanin with high purity and recovery from Spirulina (Arthrospira) platensis. J. Appl. Phycol. 23: 1-6. 